\title{
ENCONTROS SONOROS, IBÃ HUNI KUIN E ESTUDANTES DE ARTES DA UFSB
}

\author{
AUGUSTIN DE TUGNY ${ }^{1}$ \\ ALESSANDRO FACUNDES BEZERRA ${ }^{2}$ \\ DANIEL DURANS ${ }^{3}$ \\ LEONARDO HOLANDA ${ }^{4}$ \\ MÁRCIO DE ALMEIDA COSTA ${ }^{5}$
}

\section{RESUMO}

Esse texto apresenta a Formação em Artes da UFSB em suas relações com 0 Encontro de Saberes, relata a experiência de um ateliê de formação artística com a presença do mestre Ibã Huni Kuin e os desdobramentos que estudantes músicos deram às suas criações depois de sua intervenção.

\section{PALAVRAS-CHAVE}

Formação artística; Encontros de saberes; Criação Sonora; Mahku.

\section{SONOROUS ENCOUNTERS, IBÃ HUNI KUIN AND UFSB ARTS STUDENTS}

\section{ABSTRACT}

This text presents the UFSB Formation in Arts in its relations with the Meetings of Knowledge, reports on the experience of a workshop of artistic formation with the presence of the master Ibã Huni Kuin and the developments that student musicians gave to their creations after his intervention.

\section{KEYWORDS}

Artistic formation; Meeting of knowledge; Sound creation; Mahku.

\section{RENCONTRES SONORES, IBÃ HUNI KUIN ET ÉTUDIANTS EN ARTS DE LA UFSB}

\section{RÉSUMÉ}

Ce texte présente la Formation en Arts à la UFSB et ses relations avec les Rencontres de Savoirs, relate l'expérience d'un atelier de formation artistique en présence du maître Ibã Huni Kuin et les développements que les étudiants musiciens donnèrent à leurs créations à la suite de son intervention.

1 Professor adjunto do Centro de Formação em Artes e Educação da UFSB (CFAC-UFSB), atugny.ufsb@gmail.com.

2 Estudante do Bacharelado Interdisciplinar em Artes (CFAC-UFSB), michaeljacksondoarrocha@gmail.com.

${ }^{3}$ Estudante do Bacharelado Interdisciplinar em Artes (CFAC-UFSB), danielsantosdurans@gmail.com.

${ }^{4}$ Licenciado e bacharel em Artes pela UFSB, estudante do curso de Som, Imagem, Movimento (CFAC-UFSB), leonardo.holanda2014@hotmail.com.

5 Bacharel em Artes pela UFSB, professor da Rede Municipal de Educação de Cuiabá, marcio costaa@hotmail.com. 


\section{MOTS-CLÉ}

Formation artistique; Rencontre de savoirs; Création sonore; Mahku.

\section{ENCUENTROS SONOROS, IBÃ HUNI KUIN E ESTUDIANTES DE ARTES EN LA UFSB}

\section{RESUMEN}

Este texto presenta la Formación en Artes de la UFSB en sus relaciones con el Encuentro de Conocimientos, relata la experimentación de un taller de formación artística con la presencia del maestro Ibã Huni Kuin y los desarrollos que los estudiantes músicos dieran a sus creaciones luego de su intervención.

\section{PALABRAS CLAVE}

Formación artística; Encuentro de conocimientos; Creación Sonora; Mahku. 


\section{ENSINO DAS ARTES NA UFSB}

A UFSB, uma das mais jovens Universidades Federais do Brasil, implantada na região Sul da Bahia em três campi e 8 colégios universitários, nasceu com vocação de desenvolver um modelo de educação integrador, interdisciplinar e intercultural inserido nas realidades sociais, econômicas e culturais da região. Seus marcos conceituais integram as propostas desenvolvidas por Anísio Teixeira com a Universidade Popular, Paulo Freire e a Pedagogia da Autonomia, a Geografia Nova de Milton Santos, a Ecologia dos Saberes de Boaventura de Sousa Santos e a Inteligência Coletiva de Pierre Lévy (UFBS, 2014, p. 20). A estrutura dos currículos em ciclos oferece uma possibilidade de formação com modularidade progressiva. Assim, segundo a proposta inicial, o currículo de Primeiro Ciclo seguido pelos estudantes se inicia por um ano (em três quadrimestres) de formação geral ${ }^{6}$ seguido de dois anos (seis quadrimestres) de bacharelado interdisciplinar nas áreas de saúde, ciências, humanidades e artes ou licenciatura interdisciplinar em artes, humanidades, linguagem, ciência e matemática. Centros de Formação em Saúde, Tecnociências, Ciências ambientais, Humanidades e Artes propõem cursos de segundo ciclo em nível de bacharelado com caráter profissionalizante e formações em nível de pós-graduação.

A proposta do Bacharelado Interdisciplinar em Artes (Bl-Artes) numa ligação íntima com a Licenciatura Interdisciplinar em Artes (LI-Artes) estabelece um primeiro ciclo comum a todos os estudantes da área de Arte, com forte ênfase no reconhecimento e na valorização dos saberes e práticas tradicionais e populares, além de ampla abertura às práticas não hegemônicas das artes. Essa proposta tem potencial transformador do campo das formações artísticas. Evitando tomar as Artes dentro dos domínios traçados por tradições que ganharam hegemonia nos processos históricos de construção do conhecimento e das profissões e superando a formação voltada estritamente ao aprendizado das técnicas artísticas, ela pretende se colocar numa perspectiva descolonizadora, evitando a exclusividade dos parâmetros eurocêntricos que predominam nos cursos superiores de artes no Brasil (TUGNY, 2020). Isso deve permitir consolidar uma visão interdisciplinar e solidária durante a formação universitária, para que os egressos possam realizar uma prática mais efetiva, inclusive no campo da promoção das Artes, construindo uma relação estendida com as possibilidades e realizações estéticas contemporâneas em situações contextualizadas de atuação em comunidade.

O eixo de formação do $\mathrm{Bl}$ e da LI em Artes é constituído por uma sequência de Ateliês que, a cada quadrimestre, permitem aos estudantes desenvolver uma proposta de práticas artísticas compartilhadas. Neles, os estudantes devem trabalhar coletivamente,

\footnotetext{
${ }^{6}$ Em 2020, o currículo foi reformulado, reduzindo o ciclo de formação geral a um quadrimestre e meio.
} 
ainda que em projetos artísticos a serem desenvolvidos individualmente, ao mesmo tempo em que participam de encontros organizados com artistas populares e mestres das comunidades tradicionais. Essa disposição permite aos estudantes integrar um conhecimento das tradições, culturas, filosofias e epistemologias dos povos presentes nas Américas em diálogo com as diversas proposições da arte contemporânea.

Em seus desdobramentos recentes, como a arte relacional, a ação artística contemporânea compreende inserção ativa nos diversos terrenos das socialidades, "na esfera das relações inter-humanas" (BOURRIAUD, 2009, p. 40). Ao mesmo tempo, ao descobrir as atuações dos artistas populares, mestres de comunidades tradicionais, pode-se observar que suas práticas artísticas não são especializadas em uma única técnica ou linguagem, tomada isoladamente, mas que eles dominam e são mantenedores de modos estéticos amplos de ser no comum, na comunidade. Trata-se então de promover um encontro entre as formas de produção da arte contemporânea, que costumam alargar ou até romper as barreiras estabelecidas pelas artes canônicas estabelecidas na tradição eurocêntrica desde o Renascimento, e as práticas das comunidades tradicionais, que se formulam numa interação de modos de fazer e de produzir possibilitados por uma herança holística que não se submete às categorias das artes colonizadoras. Desta forma, outros modos de se formar nas artes são proporcionados aos estudantes do Sul da Bahia, permitindo-lhes formas mais livres e mais abrangentes de abordar suas produções.

\begin{abstract}
"Além de considerarmos que as artes, com seus modos próprios de produção de conhecimento, saberes e fazeres, suas formas específicas de afeto e de fruição, não são simplesmente "linguagens", somos levados a constatar que essas formações específicas oriundas das belas-artes, ao perpetuarem um modelo imposto colonialmente na hegemonia eurocêntrica e monoculturalista das artes canônicas, não correspondem à maioria da produção artística contemporânea brasileira e ainda menos permitem abranger a riqueza e complexidade das expressões culturais populares e tradicionais sendo elas, no entanto, consideradas como artísticas. De fato, em quais dessas categorias oriundas das belas-artes podemos considerar um "bumba meu boi" do Maranhão ou um "cavalo marinho" de Pernambuco: teatro, dança, música, ópera, artes visuais, poesia? Nenhuma dessas abordagens, isolada ou tomadas em conjunto, dará conta da força e da riqueza da experiência artística do evento porque elas respondem fundamentalmente a outros modos de fazer e vivenciar as artes, porque elas foram elaboradas em outras bases epistemológicas" (TUGNY, 2020, p. 511).
\end{abstract}

Nessa perspectiva, um dos 6 ateliês do BI e da LI em Artes é especificamente dedicado a essa relação com os mestres dos saberes tradicionais, é o "Ateliê em Encontro de Saberes" no qual um mestre é convidado como professor visitante para trabalhar com os estudantes e com acompanhamento de um docente regular do curso durante um quadrimestre. Essa posição de professor visitante na Universidade atribuída a um mestre dos saberes tradicionais se inscreve na linha dos Encontros de Saberes na Universidade Вrasileira preconizados e incentivados pelo INCT de Inclusão no Ensino Superior e na Pesquisa coordenado pelo Prof. José Jorge de Carvalho da UnB e cuja missão é: 


\begin{abstract}
"Propiciar um espaço de experimentação pedagógica e epistêmica no ensino capaz de inspirar resgates de saberes e inovações que beneficiem a todos os envolvidos estudantes, mestres e professores. Trata-se de um desafio de grandes proporções devido ao verdadeiro abismo que separa os dois mundos que pretendemos colocar em diálogo: o mundo acadêmico, altamente letrado e centrado exclusivamente nos saberes derivados das universidades ocidentais modernas; e o mundo dos saberes tradicionais, centrado na transmissão oral e que preserva saberes de matrizes indígenas e africanas e de outras comunidades tradicionais, acumuladas durante séculos no Brasil" (CARVALHO, 2014).
\end{abstract}

No contexto da formação em Artes na UFSB esse desafio corresponde à proposta intercultural e interepistêmica que sustenta o curso de BI e de LI numa dinâmica integrada às artes contemporâneas, como se o curso se estabelecesse utopicamente como ponte nesse abismo, proporcionando encontros suspensos e uma travessia de criação poética.

No ultimo quadrimestre de 2016, o Ateliê em Encontros de Saberes do Bl-Artes e da LI-Artes do campus Sosígenes Costa convidou o mestre Ibã Huni Kuin como professor visitante.

\title{
IBÃ HUNI KUIN, MESTRE DE SABERES E PROFESSOR VISITANTE
}

Ibã Huni Kuin nasceu em 1964 na beira do rio Jordão no estado do Acre, foi registrado com o nome de Isaías Sales ${ }^{7}$. Ele é do clã Duabaku, o clã que possui a ciência das onças pintadas dentro do povo Huni Kuin, os Kaxinawa para os não indígenas.

Sua infância e juventude foram divididas entre os trabalhos escravos no seringal ao qual seu povo era submetido e sua busca pelos saberes e pela cultura ancestral dos Huni Kuin. Ele desenvolveu um interesse crescente e uma ampla formação dentro da cultura, da cosmologia e das ciências huni kuin recebendo diversas iniciações e coletando cantos, mitos e saberes entre os anciões de seu clã, começando por seu pai Tuin Huni Kuin. Seus mestres e suas mestras, anciões e anciãs do povo, lhe apresentaram e, quando possivel ${ }^{8}$, Ihe iniciaram e ensinaram as artes da tecelagem, dos Kene, esse sistema complexo de desenhos-escrita que têm por origem a pele da cobra jiboia (MAIA, 1999, p.15; LAGROU, 2007, p.119), dos trançados, da cestaria, da pintura, da tintura, da cerâmica, da culinária, da plumária, da madeira, da construção das ocas, do cultivo, das plantas que curam, das ervas perfumosas e dos banhos, da caça. Ensinaram também a história de seu povo, os mitos, a espiritualidade e os rituais que sustentam todos esses conhecimentos e essas habilidades.

\footnotetext{
${ }^{7}$ Essa apresentação biográfica foi elaborada a partir dos depoimentos de Ibã Huni Kuin durante sua estadia na UFSB.

${ }^{8}$ Algumas dessas artes e práticas - tecelagem, cerâmica, culinária - não podem ser executadas pelos homens, é o caso dos Kene que «podem ser produzidos somente por mulheres» (LAGROU, 2007, p. 59). Entretanto, elas podem ser entendidas pelos homens, como demostra o livro "Kene - a arte dos Huni Kuin", organizado por Dedê Maia (1999) e que conta com a pesquisa de professores homens Huni Kuin, no qual Ibã colaborou como autor e ilustrador.
} 
Em 1983, ele entrou no Programa de Formação de Professores Indígenas da Comissão Pró-Índio do Acre. Dentro desta formação e após, Ibã participou de muitas pesquisas sobre os conhecimentos do povo Huni Kuin que resultaram em várias publicações de sua autoria e pioneiras no Brasil.

É dentro da tradição dos cantos do Nixi Pae e na prática xamânica que Ibã desenvolveu suas principais pesquisas e atividades levantando os cantos e as diversas formas de musicalização junto aos anciões, memorizando, cantando durante rituais e trabalhando em sua transcrição ${ }^{9}$. Pela amplidão e profundidade de seus saberes e práticas, ele hoje é um Txaná, conhecedor de centenas de cantos articulados em grandes corpora e relacionados a múltiplos saberes da caça, da colheita, da pesca, da cura, dos rituais, dos batismos, das rezas, das ervas perfumosas.

A publicação do livro "Nixi Pae, o espirito da floresta" em 2005 teve grande repercussão entre as comunidades Huni Kuin, impulsionando a retomada desses cantos durante os rituais cerimoniais de ayahuasca e fazendo frente à influência das religiões ayahuasqueiras não indígenas - Santo Daime, Barquinho, União do Vegetal - onde os cantos foram substituídos por cantorias, hinos, salmos e rituais de tradição cristão e/ou espirita (PACHECO, 2014, p. 27-36).

Esses conhecimentos foram ao longo dos anos amplamente compartilhados por lbã através das publicações com porte interno ao povo Huni Kuin e externo, ampliado por sua participação em seminários e congressos. No ano de 2000, ele participou com Joaquim Maná do "Encontro Internacional de Etnomusicologia: Músicas africanas e indígenas no Brasil" onde apresentaram os cantos Huni Meka do Nixi Pae (ayahuasca). Ali Ibã lembrou que desde 1992 ele pesquisa e recolhe esse repertório junto a seu pai e aos anciões de seu povo (MANA; KAXINAWA, 2006, p. 165). A partir da experiência de escravidão do povo Huini Kuin, que ele conheceu na infância, de sua formação como professor e de suas interações com o mundo dos brancos, ele soube discernir que outros modos de existência e de convívio com a sociedade contemporânea eram possíveis. Neste sentido, ele desenvolveu estratégias de passagem entre a cultura huni kuin e as culturas urbanas e da sociedade brasileira que restabelecem a dignidade e a grandeza do povo Huni Kuin, a força e atualidade de seus saberes, e apresentam a necessidade de sua espiritualidade ancestral na contemporaneidade. Junto com seu filho Bane e os jovens aprendizes de sua família e de seu povo ele desenvolveu uma nova forma de transcrever ou de dar a ver os cantos sagrados do Nixi Pae e outros que compõem o amplo repertório sagrado dos rituais e das curas. Através

\footnotetext{
${ }^{9} \mathrm{O}$ processo de transcrição dos rituais efetuado por Ibã consiste em recolher as letras dos cantos, gravados por ele cantando ou com seus parentes, organizar e traduzi-los, colocando-os na perspectiva dos mitos e das circunstâncias de sua realização. Esse amplo trabalho iniciado na publicação do livro "Nixi Pae, o espirito da floresta" (2005) é continuado com os trabalhos de preparação do livro "Os Cantos da Memória”, a ser publicado futuramente.
} 
do desenho e da pintura, ele e os jovens mostram o que o canto carrega de sentidos, símbolos, presenças, espíritos, consolidando uma verdadeira operação de tradução intersemiótica (PLAZA, 2013). Ao fundar o coletivo Mahku (Movimento dos Artistas Huni Kuin), Ibã soube dar o impulso que projeta na contemporaneidade a força dos Huni Kuin e a infinita vibração de seus cantos e de suas visões. Ao mesmo tempo, o projeto de Ibã, ao fundar o Mahku, é de instaurar um novo estatuto para ele e seus filhos, filhas, sobrinhos, sobrinhas inseridos no movimento, e para todos os Huni Kuin. A fim de se desprender do preconceito contra os povos indígenas, que levou seus ancestrais à escravidão na exploração da borracha, Ibã aposta na condição do artista como capaz de valorizar seus parentes frente à sociedade envolvente, visando dar a eles a possibilidade de valorizar, fazer conhecer e serem reconhecidos como Huni Kuin capazes de transformar o mundo e assumir seus conhecimentos plenamente. "Não quero que meus filhos voltam a ser escravos como meus avôs, por isso quero que eles sejam artistas", nos declarou Ibã. Essa estratégia de reconhecimento está funcionando: as pinturas e os artistas do Mahku foram apresentados em diversas exposições no Brasil, na América do Sul e na França. Em 2012, convidado por Bruce Albert, Ibã apresentou o trabalho do Mahku na exposição "Histoires de voir", na Fondation Cartier em Paris. Em 2013, o Mahku integrou a exposição MIRA, na UFMG (Belo Horizonte, MG). Em 2014, o Mahku participou de dois eventos importantes em São Paulo, a instalação "Sounds of Lights" em colaboração com a artista belga Naziha Mestaoui; e a exposição "Histórias Mestiças" no Instituto Tomi Otahke, onde os desenhos e pinturas do Mahku foram apresentados em relação com uma instalação de Ernesto Neto. Em 2016, Ibã foi convidado pelo MASP a realizar uma oficina de desenho e uma roda de conversa na ocasião da exposição "Histórias da infância". Foi em 2016 também que ele se tornou um dos finalistas do prêmio PIPA de Arte Contemporânea, recebendo votação expressiva de apreciadores da arte do Mahku pelo Brasil inteiro. Em 2019, viajou pela Europa com participações em seminários, exposições, ateliês e eventos culturais na Espanha e na França.

Essa empreitada de Ibã na frente do Mahku, nesse processo de tradução-transcrição dos cantos da tradição huni kuin com sua oralidade ampliada às visibilidades imagéticas lançadas ao mundo, o coloca como um passador entre culturas, particularmente propício a fomentar encontros de saberes. O antropólogo Amilton Pelegrino de Mattos ao testemunhar Ibã restituindo os cantos Huni Meka na leitura de desenhos do Mahku constatou:

"A conjunção de canto, imagem e exegese da poética intrincada dos cantos era a expressão original de um pensamento, a criação de algo novo na zona de vizinhança entre o pensamento ocidental acadêmico e o pensamento xamânico huni kuin, mas também entre esses universos de pensamento humanos e, mediados pela cosmologia huni kuin, aqueles universos em que convergem animais, espíritos e outros como sujeitos de conhecimento" (MAHKU, IBÃ, MATTOS, 2015, p. 74). 
A possibilidade de pensamento em trânsito entre mundos através da perpetuação dos cantos sagrados carregando uma multidão de saberes ancestrais, os rituais de fertilidade como o Katxa Nawa (festa dos legumes), as miragens do Nixi Pae, leva Ibã a considerar que seus ensinamentos podem e devem se estender ao mundo ocidental, e particularmente ao universo acadêmico como meio privilegiado de transmissão de saberes e conhecimentos. "A universidade tem que aprender comigo", declarou Ibã à professora Dominique Gallois quando de sua visita ao Centro de Estudos Ameríndios da Universidade de São Paulo em 2012 (MATTOS; KAXINAWA, 2017, p. 88).

Após uma primeira visita ao campus Sosígenes Costa da UFSB em Porto Seguro durante o mês de junho de 2016, Ibã recebeu o convite para ser mestre, professor visitante do Ateliê em Encontros de Saberes do Bacharelado Interdisiciplinar em Artes no mesmo campus. O convite para ser professor visitante num curso de arte inseriu sua empreitada numa outra perspectiva de transmissão, uma outra finalidade de tradução criativa.

\section{O ATELIÊ COM IBÃ}

O Ateliê em Encontros de Saberes começou no final de setembro de 2016, nas quintas-feiras com a presença de lbã, no turno vespertino com 8 estudantes e uma professora e no turno noturno com 12 estudantes e um professor. Os primeiros encontros instauraram um espaço de respeito e de escuta atenta onde Ibã assumia uma atitude que parecia cerimoniosa, com silêncios abertos para a reflexão, e cantos do Nixi Pae reforçados pelas imagens do Mahku. Mas também houve momentos de participação ampla e festiva como na festa dos legumes, o Katcha Nawa, onde todos foram convidados a vestir folhas, dançar, cantar, desenhar. Uma experiência que marcou a todas e todos foi uma entrada na escuridão noturna do bosque do campus, sem luzes artificiais, onde, para a turma reunida num amplo círculo debaixo das árvores, Ibã cantou vários versos do ritual do Nixi Pae e de outros rituais, sua voz ecoando os ruídos da floresta, numa atenção quase religiosa de todos os presentes. Durante os encontros, Ibã contava sua história de vida, a infância dele na colheita da borracha, os mitos do povo Huni Kuin, o Nixi Pae ou ritual do cipó, a vida na floresta, a aprendizagem dos cantos com seu pai, como seu pai guardou o ritual do cipó e os cantos durante a proibição, a procura que ele mesmo fez dos cantos e dos Kene junto aos mais velhos, os sentidos dos Kene, a arte da tecelagem entre as mulheres, os dois clãs da sociedade Huni Kuin da onça pintada e da onça vermelha, os casamentos interclânicos, a festa dos legumes, o Shuku Shukuwe, princípio da vida sempre recomeçada, as ervas perfumosas. Apresentou as obras e os trabalhos do Mahku, o livro dos Kene, as cores e seus significados, a força que vem dos alimentos, o canto na floresta.

O que marcou os estudantes, além da estranheza da língua e das palavras, dos mitos 
e das relações cosmogônicas apresentadas por Ibã, foi sua vontade de transmitir, sua generosidade em repassar seus conhecimentos e sua capacidade de inserir os outros nas práticas. Como diz o estudante Márcio: "dá a entender que tem pleno domínio do que ele sabe e repassa. E quando ele levou a gente para cantar no mato dava pra sentir uma modificação no comportamento dele, ele se adequou à situação, como numa passagem, um respeito se instaurou, uma concentração...". Essa segurança do saber e a serenidade de sua fala ao contar a situação do povo Huni Kuin durante o estado de quase escravidão no seringal fez com que a estudante Tamires estranhasse sua falta de rancor.

Após cinco sessões, a greve e a ocupação do campus interromperam as aulas e Ibã, que já tinha passado parte de seu legado, voltou para a aldeia Chico Curumim no rio Jordão.

\title{
O ATELIÊ DE CRIAÇÃO
}

Depois de três meses, a retomada das aulas permitiu aos estudantes relembrarem e definirem o que mais afetou cada um deles na presença do mestre Ibã. O incentivo à lembrança era para fazer dessa afetação passada, do que cada um gravou em sua memória, do que nela se perpetuou, a base de um trabalho artístico que ampliasse o encontro de saberes com Ibã. Entre todos os estudantes que trabalharam em seus projetos artísticos depois da visita do mestre, acompanhamos aqui o processo de quatro deles, que foram mais sensíveis à questão sonora por eles mesmos seguirem uma formação e prática musical. Outros estudantes desenvolveram trabalhos mais relacionados com as artes visuais ou as artes do corpo que também mereceriam ser analisados. Os cantos, a emissão sonora da voz de Ibã, o sentido da música, foi o que mais marcou esses estudantes, que relembraram da presença dele no ateliê nesses termos:

\begin{abstract}
A forma como a projeção da sua voz acontece é muito interessante, pois quando escutei as sonoridades do canto, percebi uma potência muito grande e de extrema importância, assim como a clareza desses sons. A partir dessa visão, analisei que a voz, antes de se projetar ao ambiente externo, entra em forte ressonância com as partes do corpo.
\end{abstract}

Diz o Daniel que é guitarrista, e completa, evocando a qualidade de escuta que a voz de Ibã necessita, tanto pela emissão sonora quanto pelo curso das narrativas:

Ao escutar Ibã pude ter contato com outra visão do mundo pela forma como ele nos diz e explica sobre a coisas, e que exige uma atenção maior de nossa parte. A abordagem ao se referir a um mito, por exemplo, difere da nossa ideia de história. Existe uma construção diferenciada da narrativa que causa certa estranheza ao ouvir os cantos.

Para Leonardo que tem formação de trombonista, o que marcou foi:

... o quanto diferente é a questão da emissão das notas. É incrivel, por não ter uma escala ou por não seguir a escala ocidental na qual estamos habituados. A emissão sonora é feita em sua maioria sem intervalos e isso consegui perceber bem, pois no trombone, que é o instrumento que toco, vejo isso ser feito por meio do glissando no qual posso fazer correr a vara sem pular de uma nota para a outra. 


\section{E acrescenta numa observação mais técnica:}

A respiração foi também um ponto importante a se observar por ser também uma característica dos instrumentos de sopro, pois nesse processo de inspirar e expirar, o Ibã consegue armazenar muito ar, o que the permite cantar frases inteiras com bastante intensidade e, na parte da expiração, algo mais impressionante: ele expira tanto pela boca quanto pelo nariz o que permite um som diferente que ele chama de som nasal.

Márcio, baterista e luthier de percussões, por sua vez ficou muito sensível a questões de tempo no canto de Ibã, colocando ele em relação com sua própria prática:

No encontro com Ibã, percebi em seus cantos a presença de micro espaços, aos quais não damos atenção quando estamos muito focados nos tempos e contratempos em nossa música ocidental. Buscamos somente a contagem desses espaços para que, de alguma forma, possamos nos encontrar ou desencontrar em determinados pontos dessa execução, podendo assim ter controle sobre ela de forma ordenada.

E continua sobre a ampliação da percepção que o canto huni kuin propicia:

Indo mais a fundo de meu entendimento, posso colocar que me deparei com momentos em que o Ibã faz desses cantos uma abertura, onde comecei a visualizar esses contrapontos e micro-espaços na forma primeiramente do silêncio. Após isso, percebi ao redor de nós toda uma evolução de sons e movimentos, como por exemplo, ouvindo minha própria respiração, meus batimentos cardíacos, quantos piscar de olhos se davam, e analisando quantos minutos ou segundos ficávamos imóveis. Isso tudo te leva a perceber uma série de eventos. Tudo isso vai te dando informações de tudo que se relaciona com seu corpo naquele momento.

Alessandro, cantor, lembra dos cantos huni kuin trazidos por lbã

... como verdadeiros arquivos para perpetuar uma cultura dos saberes adquiridos durante milênios. Devem ter surgido em meio a guerras, doenças, alegrias, encontros e desencontros, uma ponte de ligação, tanto para o passado como o futuro. Tele-transporte sonoro tão poderoso, capaz de levar junto os sentimentos de diferentes gerações a um lugar só.

Isso o leva a uma reflexão sobre as potências do canto que vai além da referência direta à experiência vivenciada com Ibã:

É o momento que descobrimos através do canto que o indivíduo não é separado de tudo que o cerca e sim parte de tudo que há no mundo. Os sons têm o poder de construir e reconstruir, de encontrar o que foi perdido. Quando cantamos, os sons transportam nossos corpos e perdemos a noção do tempo. Os sons nos identificam, curam nossas almas, nossas doenças. Os sons não se acovardam e são eles, os sons, os primeiros a entrar na guerra, derrotam nossos inimigos, acalmam o ódio. Os sons são personificação dos nossos mortos invisiveis, mas visiveis ao ouvido, porta de entrada para a sabedoria e o conhecimento, conhecimento esse adquirido através do som macio e encantador que tanto nos hipnotizou e como passarinhos e animais da floresta que somos, aprendemos a reverenciar e respeitar um pedaço de nós que parecia paralisado.

Para todos, a experiência sonora vivenciada com lbã abriu para outra forma de abordar e fazer música, desconstruiu parte dos padrões ocidentais nos quais eram formados e os incentivou a propor uma criação sonora renovada que colocasse em jogo o que Daniel chamou de ressonância, uma ressonância temporal e física que se estabelece na passagem dos cantos de geração para geração:

Os cantos são passados de pai para filho e existe uma complexidade que vai além do aprendizado de uma nova língua, mas está nos detalhes únicos daqueles sons. Tal complexidade também se dá na linha melódica, pois as notas são diferentes, uma métrica 
singular, que não pode simplesmente ser copiada por uma guitarra ou violão. Entender torna-se viver e vivenciar, algo que há tantas gerações é refinado. A ressonância acontece a todo instante.

No entanto, o início do processo criativo se fez pela imitação ou uma tentativa de reprodução ou mesmo de apropriação do universo sonoro cantado huni kuin trazido pelo mestre.

Em nosso primeiro encontro, já com nossos instrumentos habituais, trombone, guitarra e percussão, tentamos reproduzir alguns sons que conseguimos identificar nas músicas apresentadas pelo Ibã. Não foi muito difícil conseguir essa reprodução, principalmente por essa semelhança da emissão de notas pelo glissando da vara do trombone e também pela extensão emitida não ser muito ampla. Em algumas músicas não chega a uma oitava.

Mas ao mesmo tempo, lembrando da transcrição dos cantos em imagens que os artistas do Mahku fazem, tentaram dar uma visibilidade aos sons emitidos pelos instrumentos. Com grãos de arroz sobre uma placa vibrante ao som procuraram visualizar as frequências da emissão sonora. Daniel lembra:

Começamos a trabalhar em cima da ressonância, do formato de canto em cânones que percebemos em alguns vídeos e nos intervalos musicais peculiares que não são temperados. Desta forma, se iniciou uma pesquisa por questões que envolvem esses assuntos. Tivemos então a ideia de montar um mecanismo que pudesse transmitir a frequência sonora para outro objeto e, a depender da frequência, criar desenhos. Não mais com Ibã, a prática aconteceu utilizando uma caixa de som amplificadora e sobre a pele dos tambores que Márcio possui e fabrica, colocamos arroz. Ligamos a guitarra para tentar fazer com que o arroz vibrasse e formasse desenhos. Houve um problema, pois o arroz não formou nenhum desenho, mas a partir da experiência chegamos à proposta de trabalhar a música em cima da microfonia.

Nesse processo experimental sobre ressonância, frequências, vibração, microfonia, outras durações e alturas do som, os estudantes chegaram à proposta de construir seus próprios instrumentos, numa invenção organológica.

Foi sugerido pelo professor que trabalhássemos uma forma de definir as notas de forma livre, pois trabalhar com sonoridades indígenas implica uma desconstrução de características como a escala ocidental. Foi quando o Márcio comentou que poderíamos, ao invés de usar nossos instrumentos habituais, recriar formas de fazer música. Logo, deveríamos pensar em formas de construção e desenvolvimento de instrumentos que atendessem à questão de ter a liberdade de tocar qualquer notar fora da métrica ocidental. Iniciamos um processo de pesquisa sobre os tipos de instrumentos (alguns que eu nem conhecia).

Em sala de aula, acompanhando as investigações, os estudantes foram apresentados a diversas formas de canto e de criação sonora oriundas de várias tradições culturais que podiam estabelecer relações ou referências para seus trabalhos. Por exemplo: as noções de altura, intensidade, timbre e duração, mantras indianos, canto harmônico da Mongólia, canto gregoriano, canto inuit, cantos de ninar dos pigmeus, free jazz e improviso John Coltrane - Ornette Coleman, litofones e instrumentos de percussão do Vietnam, litofones africanos, guimbarde, balafon, bucket bass, arcos musicais de boca, berimbau Naná Vasconcellos, atonalismo - Arnold Schoenberg, organologia - André Schaeffner, música concreta - Pierre Henry - Pierre Schaeffer, etc. 
Márcio conta assim o processo que o fez passar dos instrumentos que ele tocava regularmente para uma outra forma de criação sonora:

Tentando trazer essa experiência para um contato mais próximo, resolvi criar ferramentas e recursos de percepção e entendimentos produzidos por vibrações através de ondas sonoras e que me davam esse espaço de tempo e duração, [...]. Deu-se início então a um caminho, não de técnicas avançadas, nem de rudimentos ou condicionamento físico de resistência, mas de expressão íntima do som [...]. Então perdi o formato tão necessário e obrigatório na música ocidental da métrica, das tonalidades. Foi onde me vi vibrando em sons com variantes em repetições, tensões de baixa, alta e média frequência percebidos por meus ouvidos. Baquetes foram dando lugar às mãos e à voz, a pele do tambor deixou de ser um elemento feito para receber o impacto da madeira repetidas vezes. [...]. Como tratar de uma questão de sons onde precisamos de uma percepção do seu interior e de sua relação com o mundo? Dai vem que a sensação comum a todos os seres humanos, essa vibração inicial a todos os sons, como poderia ser provocada e controlada. Sem nenhuma ligação com as notas musicais, nem com os ritmos, e atingindo uma dimensão espiritual.

Trabalhando incessantemente por horas, montei uma estrutura que deu um resultado que estimo ser positivo até então. Pois me libertei de uma estrutura já existente e criei minha própria, usando uma caixa amplificadora de baixo, um microfone para bumbo, uma pele de bumbo e sal grosso. A partir de uma batida na pele, captada pelo microfone, retransmitida pela caixa acústica, a pele entra em vibração, fazendo dançar os grãos de sal que ao contato com a pele fazem com que ela emita um som, de novo captado pelo microfone, retransmitido pela caixa acústica num movimento perpétuo de vibração, captação, emissão.

De mesmo modo, Leonardo e Daniel inventam instrumentos que permitem encontrar uma nova forma de produção sonora, vizinha a essa que eles costumam praticar.

Pedi alguns canos e comecei a tentar fazer algo, pensei inicialmente em uma flauta transversal por ser mais fácil de construir, mesmo não sabendo como tocar. [...] Inicialmente pensei em fazer a flauta num cano de 20, mas depois resolvi fazê-la de um cano de 25, pois assim seria uma flauta tenor, mesma voz que meu trombone. [...] Peguei o cano de 20 e o coloquei dentro do cano de 25, tentei tocar e o som saiu com mais facilidade. Fui puxar o cano para fora enquanto tocava e aquele som foi se alterando ao passo que ia puxando. Fiz algumas outras alterações e a flauta ficou com uma vara. E tinha conseguido me aproximar do trombone, mesmo que somente com a vara pois a embocadura é totalmente diferente [...]. Com o instrumento feito agora tinha que aprender a tocar. Em frente ao espelho, comecei a tocar e identificar as notas e fui anotando as posições. Assim como as notas que identificamos nas escalas dos Huni Kuin, a extensão desse instrumento não chegava a uma oitava.

Daniel, por sua parte, construiu um cordofone de mesa ampliado eletricamente com uma corda única e que pode ser tocado por percussão, ou pizzicato, ou como um slide guitar, possibilitando uma grande diversidade de sons sem escala predeterminada.

Alessandro é um cantor que se apresenta com o nome artístico de Michael Jackson do Arrocha, e que adotou a arte da paródia para denunciar as condições de vida e de morte da juventude das periferias de Porto Seguro. De seu lado, perseguiu uma estratégia que the permitisse estabelecer uma relação direta com representantes das comunidades pataxó presentes no território local e colocar em jogo os preconceitos e formulações do encontro colonial entre sociedades e os modelos de opressão decorrentes. A partir de leituras sobre a situação histórica e atual dos povos indígenas, montou uma expedição à aldeia pataxó da Jaqueira trazendo com ele um espelho, uma garrafa e uma corda, com a aposta de que a 
apresentação desses três objetos aos índios Pataxó iria abrir uma conversa sobre o escambo do contato original, a dizimação dos povos originários pelo álcool e o suicídio.

Eu estava muito confiante pois aqueles textos me diziam até mesmo as respostas que levaria comigo em meu encontro com os Pataxó. Pensava que quando eu colocasse esses três objetos diante do homem pataxó, que iria ser "meu objeto de pesquisa", dali em diante poderia trabalhar. [...] Meu encontro com o homem pataxó aconteceu quando este cruzava meu caminho. Parei a moto e comecei a conversar [...] minha conversa foi muito perturbadora. Primeiro que suas vestimentas não condiziam com o índio de meu imaginário. Isso me levava a desconfiar de suas origens indigenas, e quando apresentei os famosos objetos - a garrafa, a corda, o espelho - que tanto me perturbavam, e que na minha ideia, perturbariam esses povos também, ele não respondeu nada daquilo que eu esperava, que era justamente a resposta que eu mesmo tinha adquirido a partir das leituras dos textos. Fiquei decepcionado e me sentia até certos momentos ridicularizado pelo homem pataxó. Mas comecei a perceber uma coisa: nem todos os povos sofreram as mesmas questões e abusos, eles foram diferentes por diversas razões que talvez nem saibamos quais foram.

A partir dessa constatação da relatividade da situação indígena em suas relações com os brancos, Alessandro aprende

...que a força da continuidade de uma cultura é feita através dos sentidos que são preparados para facilitar nosso convívio e integração viva dentro da sociedade, um como parte de tudo. Esses sentidos são provocados pela cultura que nos cerca e que nos permite utilizar essas sabedorias para criar uma sociedade justa, onde cada um pode ter o seu papel sem que nenhum de nós tenha o sentimento de poder maior que o outro. São esses encontros que acabam criando outras politicas da força, a força de nossas culturas, só divididas por que não sabemos de nada.

Os quatro estudantes, ao final do quadrimestre, apresentaram um longo improviso sonoro, tocando seus novos instrumentos, Alessandro lendo o texto de sua epopeia ao encontro dos Pataxó, todos numa escuta atenta dos outros, num improviso de descobertas conjugadas, onde ressoa a lembrança ativa da presença de Ibã, a permanência dos cantos Huni Kuin.

\section{ALGUMAS REFLEXÕES NÃO CONCLUSIVAS}

Entre a visita de Ibã e a retomada dos trabalhos no Ateliê em Encontro de Saberes se passaram os três meses de greve. Isso fez com que a experiência inicial, o impacto de sua presença, da escuta de seus cantos, a força das experiências que ele fez viver aos estudantes, se decantaram e possibilitaram uma forma de criação que funcionou como um depósito dos ensinamentos já reformulado pela memória, apurado pelo esquecimento. Esse distanciamento possibilitou uma atitude mais consciente do legado da visita do mestre, e evitou que, no embalo de sua presença, sua influencia fosse de imediato absorvida e restituída sob formas da apropriação superficial dos gestos, visualidades e sonoridades trazidas à experiência dos estudantes. No domínio das artes, e particularmente nos espaços de formação das artes ditas "eruditas", esse risco está sempre em jogo quando do contato com mestres dos saberes ou comunidades tradicionais. Além de um interesse de 
"espetacularização" e "canibalização", uma prática de pilhagem e cópia imediatista de suas formas expressivas como material criativo disponível na tradição colonialista de extração de riquezas (CARVALHO, 2010). Realizar Encontros de Saberes em um curso de Artes sempre possibilita esses riscos. A presença de Ibã na primeira parte do ateliê, apresentando junto às tradições e conhecimentos do povo Huni Kuin as diversas práticas de tradução que ele desenvolveu e experimentou como o Mahku, antecipando uma forma de transcriação contrária à cópia (CAMPOS, 2011, p.27), providenciou aos estudantes a possibilidade de criação sem plágio, evitando a apropriação direta e superficial dos ensinamentos. No segundo tempo, o acompanhamento do ateliê por um professor docente do curso de Artes permitiu guiar os estudantes no aprofundamento da experiência de encontro de saberes com uma orientação crítica, alertando eles quando se deixavam levar a uma apropriação direta dos gestos, cantos, imagens do mestre Ibã. O tempo de suspensão entre esses dois momentos permitiu também aos estudantes colocarem em perspectiva sua própria formação e implicação no fazer artístico e na sociedade.

A partir de seus interesses em música e artes sonoras, os estudantes, emulados pelo trabalho do Mahku na transcrição-transcriação dos cantos para as imagens, tentaram desenvolver uma forma de tradução intersemiotica direta entre emissão sonora e visualidade mediada por recursos eletrônicos e mecânicos. Esse processo criativo aposta na mediação tecnológica como garantia da interação "direta". Esse havia sido o mesmo processo adotado pela artista Naziha Mestaoui na instalação "Sounds of Lights", realizada em associação com o Mahku na cidade Matarazzo em São Paulo em 2014. Nesta instalação, uma lamina d'água colocada em vibração pela emissão sonora dos cantos huni kuin refletia luzes que animavam a gigantesca pintura de uma jiboia cercando todo o espaço, numa tentativa de "fazer ver o som" (MATTOS; KAXINAWA, 2018, p. 53). Os estudantes não tinham conhecimento dessa instalação, mas fizeram a mesma aposta da intermediação tecnológica para tentar providenciar uma experiência sinestésica que finalmente não funcionou. Depois dessa primeira tentativa, eles seguiram para outras investigações mais distanciadas da referência direita aos trabalhos do Mahku e aos cantos do mestre Ibã, mas continuando a trabalhar nas aberturas que a presença do mestre e as experiências vividas com ele, bem como seus ensinamentos sobre a vida Huni Kuin, fizeram em seus conhecimentos e práticas musicais. Assim, podemos constatar que a produção que eles desenvolveram em decorrência desse encontro de saberes reformula suas posições como artistas em formação para abrir suas pesquisas à produção de novas sonoridades pela invenção de novos aparatos, uma luteria experimental que encontra diversas tradições organológicas (o cordofone desenvolvido por Daniel, por exemplo, referencia a guitarra elétrica, o slide guitar, mas também o berimbau, instrumento muito presente na região), pela descoberta de outros repertórios, ampliando o campo de possíveis referências. 
Além disso, a visita de Ibã teve como principal legado no processo de formação artística desses estudantes em artes particularmente interessados na produção sonora a ampliação de sua escuta, de sua sensibilidade ao universo sonoro. Eles desenvolveram uma consciência que os sons, e as experiências de escuta e de emissão deles, carregam conhecimentos e possibilidades de abertura, reconhecimento do outro e da diversidade do mundo do qual eles são parte. A passagem entre mundos que o mestre lbã efetua se abriu também para os estudantes que o acompanharam nessa experiência da UFSB.

\section{REFERÊNCIAS}

BOURRIAUD, Nicolas. Estética relacional. São Paulo: Martins Fontes, 2009.

CAMPOS, Haroldo de. Da transcriação, poética e semiótica da operação tradutora. Belo Horizonte: FALE/UFMG, 2011. Disponível em: https://www.academia.edu/15390705/Haroldo de Campos a transcria\%C3\%A7\%C3\%A30_po\%C3\%A9tic a Acesso em: 18 de agosto de 2020.

CARVALHO, José Jorge de. "Espetacularização" e "Canibalização" das Culturas populares na América Latina. Revista ANTHROPOLÓGICAS, v. 21, n. 1, p. 39-76, 2010.

CARVALHO, José Jorge de. Encontro de Saberes, INCTI, CNPq, UnB, 2014. Disponível em: https://inctinclusao.com.br/encontro-de-saberes/encontro-de-saberes. Acesso em: 18 de agosto de 2020.

KAXINAWA, Isaías Sales Ibã. Nixi pãe: o espírito da floresta. Rio Branco: CPI-AC, 2006.

LAGROU, Els. A fluidez da forma: arte, alteridade e agência em uma sociedade amazônica (Kaxinawa, Acre). Rio de Janeiro; Topbooks, 2007.

MAHKU; IBÃ, Isaías Sales; MATTOS, Amilton Pelegrino. Quem é quem no pensamento huni kuin? 0 Movimento dos artistas Huni Kuin. Cadernos de Subjetividade, n. 18, p. 67-80, 2015.

MAIA, Dedê (org.). KENE - A arte dos Huni Kuin. Rio de Janeiro; CNPCP, 1999.

MANA, Joaquim; KAXINAWA, Isaias Sales Ibã. Nossa Música, tradição e atualidade dos cantos Huni Kuin. In: TUGNY, R.P.; QUEIROZ, R.C. (orgs.). Músicas africanas e indígenas no Brasil. Belo Horizonte, Editora UFMG, 2006.

MATTOS, Amilton Pelegrino; KAXINAWA, Isaías Sales Ibã. Escrita da imagem, escrita do corpo, escrita da terra - A Universidade do Movimento dos Artistas Huni Kuin. Anais da VI Reunião de Antropologia da Ciência e Tecnologia v. 3 n. $3 . \quad 2017$. Disponível em: https://ocs.ige.unicamp.br/ojs/react/issue/view/81 Acesso em: 18 de agosto de 2020.

MATTOS, Amilton Pelegrin. Màquinas de visão: 0 MAHKU - Movimento dos Artistas Huni Kuin em suas pràticas de experimentação visual. Revista Metamorfose, v.3, n.1, p.49-72, 2018.

PACHECO, Carlos Eduardo Neppel. Um psicoativo em trânsito: o caso histórico da Ayahuasca. 
Dissertação de Mestrado em História - Universidade Federal da Grande Dourados, 2014.

PLAZA, Julio. Tradução intersemiôtica. Campinas: Perspectiva, 2013.

TUGNY, Augustin de. Decolonizar as Artes na Universidade. In: GONÇALVES, G.; TUGNY, R. P. (orgs.). Universidade Popular e Encontro de Saberes. Salvador: Edufba, 2020. p. 509-529.

UNIVERSIDADE FEDERAL DO SUL DA BAHIA. Plano orientador. Itabuna. UFSB, 2014. Disponível em: http://www2.ufsb.edu.br/wp-content/uploads/Plano-Orientador-UFSB-Final1.pdf Acesso em: 18 de agosto de 2020.

Recebido em 30 de Agosto de 2020. Aprovado em 18 de março de 2021. 